\title{
Correlation Between Socio-Demographic Characteristics and Burden Among Family Caregivers of Psychotic Patients
}

\author{
Amal Ahmed ${ }^{1} \quad$ Prof.Alaa El Din Darweesh ${ }^{2}$ prof. Ikram Mohamed ${ }^{3}$ Assis.Prof, Zamzam Ahmed ${ }^{3}$ \\ 1.Faculty of Nursing and Mental Health, South valley University, Egypt \\ 2.Faculty of Medicine, Assuit University, Egypt \\ 3.Faculty of Nursing and Mental Health, Assuit University, Egypt
}

\begin{abstract}
A descriptive study using a convenience sample of family caregivers of psychotic patients recruiting from outpatient clinic and inpatients department in the Psychiatry and Neurology Hospital at Assiut University. They interviewed individually by using Socio-Demographic sheet and Burden Assessment Scale. More than forty percent of caregivers $(41.9 \%$ ) were in the age group, ranged from 45 to less than 60 years and $66.7 \%$ of them were females. family caregivers had the highest mean score of time perspective burden (7.3 \pm 2.7$)$ followed by financial problems $(2.2 \pm 1.2)$ and personal distress $(7.2 \pm 2.7)$. It can be concluded that, family caregivers of psychotic patients were highly suffering from burden related to time perspective and financial burden.
\end{abstract}

Keywords: burden, family caregivers, and psychotic patients.

DOI: $10.7176 / \mathrm{JHMN} / 70-06$

Publication date: January $31^{\text {st }} 2020$

\section{Introduction}

Currently up $90 \%$ of people with mental disorders live with relatives who provide them with long-term practical and emotional support. This shift has resulted in the transferal of the day-to-day care of people with mental disorders to family members (Schulze \& Rössler, 2005). Although, prevention of long-time hospitalization reduces stigmatization and increases quality of life for psychotic patients, it changes the situation of relatives. Restricted hospital admissions and reduced length of inpatient treatment inversely increase burden on relatives and many caregivers are suffering from ongoing distress (Boye et.al, 2001).

Burden of care is a global issue affecting family caregivers in both developed and developing countries. Reine et al., 2003 defined burden on the family as the consequences for those in close contact with a severely disturbed person with mental health problems. In addition, burden may be defined as the presence of problems, difficulties or adverse effects which affect the lives of psychotic patients' caregivers. It involves the breakdown of reciprocal arrangements that people maintain in their relationship (Swaroop et. al, 2013).

Caregiver burden has been defined as a negative reaction to the impact of providing care on caregivers' social, occupational and personal roles (Papastavrou et.al, 2007). Also, it is a psychological state resulting from physical work and emotional and social pressure associated with caring. It has been described as having two components: objective burden which relates to the tangible impact of caregiving on a caregiver's life (e.g., financial loss and time lost from daily activities) and subjective burden which refers to the caregiver's perception of burden of care (Logdberg et.al, 2004).

\section{Methods}

\subsection{Sample}

A convenient sample of family caregivers of one hundred (100) psychotic patients selected and the total number of them were 141 persons. The study was conducted at the outpatient clinic and inpatient department in the Psychiatry and Neurology Hospital at Assiut University which received all cases from governorates of Upper Egypt being the only specialist currently in psychiatric medicine. The actual study was carried out on a group of ten family caregivers of psychotic patients. Family caregivers were interviewed individually by using sociodemographic sheet, and burden assessment scale (BAS).

\subsection{Inclusion criteria:}

- A family caregiver defined as person who provides any type of physical, economic and/or emotional care for psychotic patients and is living permanently with the patient at home.

- Caregivers of patients with psychotic disorders as (schizophrenia, mood disorders with psychotic features, schizoaffective disorder, delusional disorder, brief psychotic disorder).

\subsection{Exclusion criteria:-}

- Caregivers of patients with dual diagnosis as (substance/medication-induced psychotic disorder).

- Caregivers with chronic medical illness

- Caregivers who provide economic resources but unavailable because travelling abroad. 


\subsection{Statistical analysis}

- The raw data were assorted and coded and transferred into specially format for computer feeding.

- The data were entered into the computer by using Statistical Package of Social Sciences (SPSS version 20). Statistical analysis tests included mean, standard deviation, and spearman Roh correlation coefficient, Anova, T-test, and pearson correlation.

\section{Results}

Table (1): Socio-demographic characteristics of family caregivers $(n=141):-$

\begin{tabular}{|c|c|c|}
\hline Socio-demographic characteristics of family caregivers & $\mathbf{N}=\mathbf{1 4 1}$ & $\%$ \\
\hline $\begin{array}{r}\text { Age groups } \\
15-<30 \\
30-<45 \\
45-<60 \\
60-<75 \\
\end{array}$ & $\begin{array}{l}25 \\
22 \\
59 \\
35\end{array}$ & $\begin{array}{r}17.7 \\
15.6 \\
41.9 \\
24.8\end{array}$ \\
\hline $\begin{array}{r}\text { Range } \\
\text { Mean } \pm \text { SD }\end{array}$ & $\begin{array}{c}15-70 \\
46.9 \pm 14.7\end{array}$ & \\
\hline $\begin{array}{r}\text { Sex } \\
\text { Male } \\
\text { Female }\end{array}$ & $\begin{array}{l}47 \\
94\end{array}$ & $\begin{array}{l}33.3 \\
\mathbf{6 6 . 7} \\
\end{array}$ \\
\hline $\begin{array}{r}\text { Education } \\
\text { Illiterate } \\
\text { read and write } \\
\text { Secondary } \\
\text { University }\end{array}$ & $\begin{array}{c}92 \\
18 \\
23 \\
8\end{array}$ & $\begin{array}{c}\mathbf{6 5 . 2} \\
12.8 \\
16.3 \\
5.7\end{array}$ \\
\hline $\begin{array}{r}\text { Occupation } \\
\text { Employee } \\
\text { Skilled workers } \\
\text { Non skilled workers } \\
\text { No work }\end{array}$ & $\begin{array}{c}12 \\
13 \\
12 \\
104\end{array}$ & $\begin{array}{r}8.5 \\
9.2 \\
8.5 \\
\mathbf{7 3 . 8}\end{array}$ \\
\hline $\begin{array}{r}\text { Marital status } \\
\text { Single } \\
\text { Married } \\
\text { Widow } \\
\text { Divorce } \\
\end{array}$ & $\begin{array}{c}17 \\
93 \\
28 \\
3\end{array}$ & $\begin{array}{c}12 \\
\mathbf{6 6} \\
19.9 \\
2.1 \\
\end{array}$ \\
\hline $\begin{array}{r}\text { Relative degree } \\
\text { Mother } \\
\text { Father } \\
\text { Brother/Sister } \\
\text { Husband/Wife } \\
\text { Uncle/Aunt } \\
\text { Daughter/Son }\end{array}$ & $\begin{array}{c}56 \\
24 \\
26 \\
21 \\
3 \\
11\end{array}$ & $\begin{array}{c}\mathbf{3 9 . 7} \\
17.1 \\
18.4 \\
14.9 \\
2.1 \\
7.8 \\
\end{array}$ \\
\hline $\begin{array}{r}\text { Residence } \\
\text { Rural } \\
\text { Urban } \\
\end{array}$ & $\begin{array}{c}121 \\
20\end{array}$ & $\begin{array}{l}\mathbf{8 5 . 9} \\
14.2 \\
\end{array}$ \\
\hline $\begin{array}{r}\text { Income } \\
\text { No fixed income } \\
\text { Insufficient } \\
\text { Sufficient }\end{array}$ & $\begin{array}{l}61 \\
59 \\
21\end{array}$ & $\begin{array}{l}\mathbf{4 3 . 3} \\
41.8 \\
14.9\end{array}$ \\
\hline
\end{tabular}

This table (1) showed that, the age of caregivers ranged between 15 to $<75$ years. More than forty percent of caregivers $(41.9 \%)$ were in the age group, ranged from 45 to less than 60 years and $66.7 \%$ of them were females. Also, it was shown that, the majority of the caregivers had no work with $65.2 \%$ of them were illiterate. As regards marital status, $66 \%$ of caregivers were married and $39.7 \%$ of caregivers were mothers. Most of caregivers live in rural areas $(85.9 \%), 43.3 \%$ had no fixed income and $41.8 \%$ of caregivers' patients diagnosed with schizophrenia. 
Table (2): Socio-demographic characteristics of psychotic patients $(\mathrm{N}=100)$ :-

\begin{tabular}{|c|c|c|}
\hline Socio-demographic characteristics of patients & $\mathbf{N}=\mathbf{1 0 0}$ & $\%$ \\
\hline $\begin{array}{r}\text { Age groups } \\
15-<30 \\
30-<45 \\
45-<60 \\
60-<75\end{array}$ & $\begin{array}{c}55 \\
27 \\
16 \\
2\end{array}$ & $\begin{array}{c}\mathbf{5 5 . 0} \\
27.0 \\
16.0 \\
2.0\end{array}$ \\
\hline $\begin{array}{r}\text { Range } \\
\text { Mean } \pm \text { SD }\end{array}$ & $\begin{array}{c}15-67 \\
32.1 \pm 12.4\end{array}$ & \\
\hline $\begin{array}{r}\text { Sex } \\
\text { Male } \\
\text { Female }\end{array}$ & $\begin{array}{l}35 \\
65\end{array}$ & $\begin{array}{l}35.0 \\
65.0\end{array}$ \\
\hline $\begin{array}{r}\text { Education } \\
\text { Illiterate } \\
\text { Read and write } \\
\text { Secondary } \\
\text { University }\end{array}$ & $\begin{array}{c}51 \\
18 \\
24 \\
7\end{array}$ & $\begin{array}{c}\mathbf{5 1 . 0} \\
18.0 \\
24.0 \\
7.0\end{array}$ \\
\hline $\begin{array}{r}\text { Occupation } \\
\text { Employee } \\
\text { Skilled workers } \\
\text { Non skilled workers } \\
\text { No work }\end{array}$ & $\begin{array}{c}4 \\
3 \\
4 \\
89\end{array}$ & $\begin{array}{c}4.0 \\
3.0 \\
4.0 \\
\mathbf{8 9 . 0}\end{array}$ \\
\hline $\begin{array}{r}\text { Marital status } \\
\text { Single } \\
\text { Married } \\
\text { Widow } \\
\text { Divorce }\end{array}$ & $\begin{array}{c}54 \\
35 \\
5 \\
6\end{array}$ & $\begin{array}{c}\mathbf{5 4 . 0} \\
35.0 \\
5.0 \\
6.0\end{array}$ \\
\hline $\begin{array}{r}\text { Residence } \\
\text { Rural } \\
\text { Urban }\end{array}$ & $\begin{array}{l}86 \\
14\end{array}$ & $\begin{array}{l}\mathbf{8 6 . 0} \\
14.0\end{array}$ \\
\hline $\begin{array}{r}\text { Income } \\
\text { No fixed income } \\
\text { Insufficient } \\
\text { Sufficient }\end{array}$ & $\begin{array}{c}78 \\
14 \\
8 \\
\end{array}$ & $\begin{array}{c}78.0 \\
14.0 \\
8.0\end{array}$ \\
\hline
\end{tabular}

Table (2) showed socio-demographic characteristics of patients; $55 \%$ of them within age group $15-<30$, $65 \%$ of them were females, $86 \%$ live in rural areas and $78 \%$ had no fixed income.

Table (4): Distribution of burden among family caregivers $(n=141)$ :-

\begin{tabular}{r|c|c|c|}
\hline Burden & $\begin{array}{c}\text { Range of original } \\
\text { subscales scoring }\end{array}$ & $\begin{array}{c}\text { Range of score of } \\
\text { caregivers }\end{array}$ & Mean \pm SD \\
\hline Burden subscales & $1-4$ & $1-4$ \\
Financial problems & $6-24$ & $6-21$ & $\mathbf{2 . 2} \pm \mathbf{1 . 2}$ \\
Disrupted activities & $4-16$ & $4-15$ & $10.3 \pm 4.0$ \\
Personal distress & $3-12$ & $3-12$ & $7.2 \pm 2.7$ \\
Time perspectives & $3-12$ & $3-12$ & $7.3 \pm \mathbf{2 . 7}$ \\
Guilt & $2-8$ & $2-8$ & $3.4 \pm 1.2$ \\
Basic social functioning & & $3.1 \pm 1.4$ \\
\hline
\end{tabular}

It is clear from this table that ; family caregivers had the highest mean score of time perspective burden (7.3 \pm 2.7$)$ followed by financial problems $(2.2 \pm 1.2)$ and personal distress (7.2 \pm 2.7$)$. 
Table (6) Correlation between burden and socio-demographic characteristics of family caregivers $(\mathrm{N}=141)$ :-

\begin{tabular}{|c|c|c|c|c|c|c|}
\hline \multirow[b]{2}{*}{$\begin{array}{c}\text { Socio-demographic } \\
\text { characteristics of } \\
\text { caregivers }\end{array}$} & \multicolumn{6}{|c|}{ Burden } \\
\hline & $\begin{array}{l}\text { Financial } \\
\text { problems }\end{array}$ & $\begin{array}{c}\text { Disrupted } \\
\text { activities }\end{array}$ & $\begin{array}{c}\text { Personal } \\
\text { distress }\end{array}$ & $\begin{array}{c}\text { Time } \\
\text { perspective }\end{array}$ & Guilt & $\begin{array}{l}\text { Basic social } \\
\text { functioning }\end{array}$ \\
\hline *Range of scoring & $\begin{array}{c}(\mathbf{1 - 4 )} \\
\text { Mean } \pm \text { SD }\end{array}$ & $\begin{array}{c}(\mathbf{6 - 2 4 )} \\
\text { Mean } \pm \text { SD }\end{array}$ & $\begin{array}{c}(\mathbf{4 - 1 6 )} \\
\text { Mean } \pm \text { SD }\end{array}$ & $\begin{array}{c}(\mathbf{3 - 1 2}) \\
\mathrm{Mean} \pm \mathrm{SD}\end{array}$ & $\begin{array}{c}(\mathbf{3 - 1 2}) \\
\text { Mean } \pm \text { SD }\end{array}$ & $\begin{array}{c}(\mathbf{2 - 8 )} \\
\text { Mean } \pm \text { SD }\end{array}$ \\
\hline $\begin{array}{l}\text { Age groups } \\
15-<30 \\
30-<45 \\
45-<60 \\
60-<75 \\
\text { F } \\
\text { p-value }\end{array}$ & $\begin{array}{c}1.6 \pm 0.9 \\
1.8 \pm 1.2 \\
2.4 \pm 1.2 \\
\mathbf{2 . 5} \pm \mathbf{1 . 2} \\
4.2 \\
\mathbf{0 . 0 0 7}\end{array}$ & $\begin{array}{c}9.1 \pm 4.0 \\
\mathbf{1 2 . 3} \pm \mathbf{4 . 7} \\
10.4 \pm 3.9 \\
9.7 \pm 3.6 \\
2.8 \\
\mathbf{0 . 0 4}\end{array}$ & $\begin{array}{c}6.3 \pm 2.2 \\
7.4 \pm 2.3 \\
7.1 \pm 2.6 \\
8.0 \pm 3.5 \\
2.0 \\
0.1\end{array}$ & $\begin{array}{l}6.4 \pm 2.7 \\
7.0 \pm 2.9 \\
7.6 \pm 2.9 \\
7.6 \pm 2.7 \\
1.5 \\
0.2\end{array}$ & $\begin{array}{c}3.3 \pm 0.7 \\
3.5 \pm 1.9 \\
3.4 \pm 4.1 \\
3.5 \pm 1.1 \\
0.11 \\
0.9\end{array}$ & $\begin{array}{c}3.0 \pm 1.3 \\
1.7 \pm 0.4 \\
1.3 \pm 0.2 \\
1.6 \pm 0.3 \\
0.03 \\
0.9\end{array}$ \\
\hline $\begin{array}{l}\text { Sex } \\
\text { Male } \\
\text { Female } \\
\text { T } \\
\text { P-value }\end{array}$ & $\begin{array}{c}2.2 \pm 1.2 \\
2.1 \pm 1.2 \\
0.39 \\
0.7\end{array}$ & $\begin{array}{c}10.1 \pm 3.8 \\
10.4 \pm 4.2 \\
-0.41- \\
0.7\end{array}$ & $\begin{array}{l}7.1 \pm 2.8 \\
7.4 \pm 2.8 \\
0.56 \\
0.6\end{array}$ & $\begin{array}{c}7.3 \pm 2.7 \\
7.3 \pm 2.8 \\
-0.09- \\
0.9\end{array}$ & $\begin{array}{c}3.3 \pm 0.9 \\
3.5 \pm 1.3 \\
-0.65- \\
0.5\end{array}$ & $\begin{array}{c}\mathbf{3 . 5} \pm \mathbf{1 . 8} \\
2.8 \pm 1.2 \\
2.83 \\
\mathbf{0 . 0 0 5}\end{array}$ \\
\hline $\begin{array}{l}\text { Occupation } \\
\text { Employee } \\
\text { Skilled workers } \\
\text { Non skilled workers } \\
\text { No work } \\
\text { F } \\
\text { P-value }\end{array}$ & $\begin{array}{l}1.4 \pm 0.9 \\
1.9 \pm 1.0 \\
\mathbf{2 . 9} \pm \mathbf{1 . 3} \\
2.2 \pm 1.2 \\
3.5 \\
\mathbf{0 . 0 1}\end{array}$ & $\begin{array}{c}11.3 \pm 4.2 \\
10.1 \pm 4.0 \\
10.2 \pm 4.3 \\
10.2 \pm 4.0 \\
0.3 \\
0.8\end{array}$ & $\begin{array}{l}6.2 \pm 1.7 \\
7.2 \pm 2.1 \\
7.9 \pm 3.1 \\
7.3 \pm 2.9 \\
0.8 \\
0.5\end{array}$ & $\begin{array}{l}7.1 \pm 2.8 \\
6.3 \pm 2.7 \\
7.8 \pm 2.7 \\
7.4 \pm 2.8 \\
0.7 \\
0.5\end{array}$ & $\begin{array}{c}3.3 \pm 0.6 \\
3.4 \pm 1.0 \\
3.1 \pm 0.3 \\
3.5 \pm 1.2 \\
0.4 \\
0.7\end{array}$ & $\begin{array}{c}\mathbf{4 . 4} \pm \mathbf{1 . 9} \\
3.8 \pm 1.4 \\
3.7 \pm 2.0 \\
2.7 \pm 1.1 \\
8.5 \\
\mathbf{0 . 0 0 0}\end{array}$ \\
\hline $\begin{array}{l}\text { Education } \\
\text { Illiterate } \\
\text { Read and write } \\
\text { Secondary } \\
\text { University } \\
\text { F } \\
\text { P-value }\end{array}$ & $\begin{array}{c}\mathbf{2 . 5} \pm \mathbf{1 . 3} \\
1.8 \pm 0.9 \\
1.5 \pm 0.8 \\
1.5 \pm 0.8 \\
5.9 \\
\mathbf{0 . 0 0 1}\end{array}$ & $\begin{array}{c}10.3 \pm 3.9 \\
9.0 \pm 2.8 \\
11.0 \pm 4.8 \\
11.0 \pm 5.3 \\
0.96 \\
0.4\end{array}$ & $\begin{array}{c}7.5 \pm 2.9 \\
6.2 \pm 2.1 \\
7.1 \pm 2.3 \\
6.5 \pm 3.1 \\
1.3 \\
0.3\end{array}$ & $\begin{array}{l}7.6 \pm 2.7 \\
7.0 \pm 2.5 \\
6.3 \pm 3.0 \\
7.5 \pm 3.3 \\
1.5 \\
0.2\end{array}$ & $\begin{array}{l}3.4 \pm 1.3 \\
3.3 \pm 0.6 \\
3.5 \pm 1.0 \\
3.6 \pm 1.8 \\
0.2 \\
0.9\end{array}$ & $\begin{array}{c}2.8 \pm 1.2 \\
3.2 \pm 1.3 \\
3.7 \pm 1.9 \\
3.5 \pm 2.0 \\
2.7 \\
\mathbf{0 . 0 4}\end{array}$ \\
\hline
\end{tabular}

$\mathrm{N}$ : B high mean score mean high burden

*Range of scoring = minimum and maximum score of each subscale of burden. 
Table (6): Correlation between burden and socio-demographic characteristics of family caregivers $(\mathrm{N}=141)$ cont.:-

\begin{tabular}{|c|c|c|c|c|c|c|}
\hline \multirow{2}{*}{$\begin{array}{l}\text { Socio-demographic } \\
\text { characteristics of } \\
\text { family caregivers }\end{array}$} & \multicolumn{6}{|c|}{ Burden } \\
\hline & $\begin{array}{l}\text { Financial } \\
\text { problems }\end{array}$ & $\begin{array}{c}\text { Disrupted } \\
\text { activities }\end{array}$ & $\begin{array}{c}\text { Personal } \\
\text { distress }\end{array}$ & $\begin{array}{c}\text { Time } \\
\text { perspective }\end{array}$ & guilt & $\begin{array}{l}\text { Basic social } \\
\text { functioning }\end{array}$ \\
\hline *Range of scoring & $(1-4)$ & $(6-24)$ & $(4-16)$ & $(3-12)$ & $(3-12)$ & $(2-8)$ \\
\hline & \multicolumn{6}{|c|}{ Mean \pm SD } \\
\hline $\begin{array}{l}\text { Marital status } \\
\text { Single } \\
\text { Married } \\
\text { Widow } \\
\text { Divorce } \\
\text { F } \\
\text { P-value }\end{array}$ & $\begin{array}{c}1.3 \pm 0.7 \\
2.3 \pm 1.2 \\
\mathbf{2 . 5} \pm \mathbf{1 . 3} \\
1.3 \pm 0.6 \\
4.8 \\
\mathbf{0 . 0 0 3}\end{array}$ & $\begin{array}{c}8.8 \pm 3.8 \\
10.4 \pm 4.2 \\
11.1 \pm 3.7 \\
9.0 \pm 2.7 \\
1.3 \\
0.3\end{array}$ & $\begin{array}{c}6.1 \pm 2.2 \\
7.1 \pm 2.6 \\
\mathbf{8 . 5} \pm \mathbf{3 . 2} \\
6.0 \pm 2.6 \\
3.5 \\
\mathbf{0 . 0 1}\end{array}$ & $\begin{array}{c}5.4 \pm 2.3 \\
7.4 \pm 2.8 \\
\mathbf{8 . 2} \pm \mathbf{2 . 3} \\
6.0 \pm 2.0 \\
4.2 \\
\mathbf{0 . 0 0 7}\end{array}$ & $\begin{array}{c}3.1 \pm 6.3 \\
3.4 \pm 1.3 \\
3.5 \pm 1.0 \\
3.0 \pm 0.0 \\
0.6 \\
0.6\end{array}$ & $\begin{array}{c}2.6 \pm 1.1 \\
3.2 \pm 1.5 \\
3.1 \pm 1.5 \\
2.3 \pm 0.6 \\
0.8 \\
0.5\end{array}$ \\
\hline $\begin{array}{l}\text { Relative degree } \\
\text { Mother } \\
\text { Father } \\
\text { Brother/sister } \\
\text { Husband/wife } \\
\text { Uncle/aunt } \\
\text { Daughter/son } \\
\text { F } \\
\text { P-value }\end{array}$ & $\begin{array}{c}2.4 \pm 1.2 \\
2.6 \pm 1.2 \\
1.5 \pm 0.8 \\
2.5 \pm 1.4 \\
2.0 \pm 1.7 \\
1.3 \pm 0.5 \\
4.3 \\
\mathbf{0 . 0 0 1}\end{array}$ & $\begin{array}{c}13.0 \pm 6.1 \\
10.4 \pm 3.8 \\
10.3 \pm 4.0 \\
11.0 \pm 4.8 \\
9.8 \pm 3.8 \\
9.0 \pm 4.0 \\
0.7 \\
0.6\end{array}$ & $\begin{array}{c}\mathbf{1 0 . 0} \pm \mathbf{5 . 6} \\
7.5 \pm 2.8 \\
6.2 \pm 2.0 \\
7.9 \pm 2.8 \\
7.5 \pm 2.8 \\
5.8 \pm 2.0 \\
2.4 \\
\mathbf{0 . 0 3}\end{array}$ & $\begin{array}{c}\mathbf{9 . 3} \pm \mathbf{1 . 2} \\
8.3 \pm 2.7 \\
6.7 \pm 2.5 \\
6.2 \pm 2.4 \\
7.6 \pm 2.7 \\
4.6 \pm 2.0 \\
5.5 \\
\mathbf{0 . 0 0 0}\end{array}$ & $\begin{array}{c}3.6 \pm 1.6 \\
3.3 \pm 1.0 \\
3.2 \pm 0.7 \\
3.4 \pm 1.0 \\
3.3 \pm 0.6 \\
3.3 \pm 0.5 \\
0.6 \\
0.7\end{array}$ & $\begin{array}{c}2.7 \pm 1.1 \\
3.0 \pm 1.6 \\
3.3 \pm 1.7 \\
3.5 \pm 1.5 \\
4.3 \pm 3.2 \\
2.6 \pm 1.1 \\
2.3 \\
0.04\end{array}$ \\
\hline $\begin{array}{l}\text { Residence } \\
\text { Rural } \\
\text { Urban } \\
\text { T } \\
\text { P-value }\end{array}$ & $\begin{array}{c}\mathbf{2 . 3} \pm \mathbf{1 . 2} \\
1.5 \pm 0.9 \\
2.99 \\
\mathbf{0 . 0 0 3}\end{array}$ & $\begin{array}{c}9.8 \pm 3.9 \\
\mathbf{1 3 . 1} \pm \mathbf{4 . 1} \\
-3.43 \\
\mathbf{0 . 0 0 1}\end{array}$ & $\begin{array}{c}6.9 \pm 2.5 \\
\mathbf{9 . 2} \pm \mathbf{3 . 3} \\
-3.62 \\
\mathbf{0 . 0 0 0}\end{array}$ & $\begin{array}{c}7.1 \pm 2.7 \\
\mathbf{8 . 5} \pm \mathbf{2 . 6} \\
-2.26 \\
\mathbf{0 . 0 2}\end{array}$ & $\begin{array}{c}3.4 \pm 1.2 \\
3.6 \pm 1.1 \\
-0.76 \\
0.4\end{array}$ & $\begin{array}{c}2.9 \pm 1.3 \\
\mathbf{4 . 3} \pm \mathbf{1 . 7} \\
-4.23 \\
\mathbf{0 . 0 0 0}\end{array}$ \\
\hline $\begin{array}{l}\text { Income } \\
\text { No fixed income } \\
\text { Insufficient } \\
\text { Sufficient } \\
\text { F } \\
\text { P-value }\end{array}$ & $\begin{array}{c}2.1 \pm 1.2 \\
\mathbf{2 . 6} \pm \mathbf{1 . 2} \\
1.3 \pm 0.6 \\
9.8 \\
\mathbf{0 . 0 0 0}\end{array}$ & $\begin{array}{c}10.2 \pm 4.2 \\
10.5 \pm 4.1 \\
9.8 \pm 3.7 \\
0.3 \\
0.8\end{array}$ & $\begin{array}{c}5.7 \pm 2.5 \\
\mathbf{7 . 9} \pm \mathbf{3 . 0} \\
6.9 \pm 2.0 \\
3.4 \\
\mathbf{0 . 0 3}\end{array}$ & $\begin{array}{c}7.2 \pm 3.0 \\
7.7 \pm 2.6 \\
6.5 \pm 2.6 \\
1.5 \\
0.2\end{array}$ & $\begin{array}{c}3.4 \pm 1.4 \\
3.4 \pm 1.1 \\
3.3 \pm 0.6 \\
0.1 \\
0.9\end{array}$ & $\begin{array}{c}2.6 \pm 1.0 \\
3.3 \pm 1.6 \\
\mathbf{3 . 6} \pm \mathbf{1 . 8} \\
6.4 \\
\mathbf{0 . 0 0 2}\end{array}$ \\
\hline
\end{tabular}

$\mathrm{N}: \mathrm{B}$ high mean scores mean high burden

*Range of scoring $=$ minimum and maximum score of each subscale of burden

Table (6) showed that, the age group 30-<45 have significantly higher mean score of disrupted activities $(12.3 \pm 4.7, \mathrm{p}=0.04)$ than other age groups and the age group $60-<75$ have significantly the highest mean score of financial problems $(2.5 \pm 1.2, \mathrm{p}=0.007)$. Also, male caregivers have significantly higher mean score of basic social functioning than females $(3.5 \pm 1.8, \mathrm{p}=0.005)$.

Regarding occupation, non- skilled workers have significantly higher mean score of financial problems $(2.9 \pm 1.3, \mathrm{p}=0.01)$ than others and employee has significantly the highest mean score of basic social functioning $(4.4 \pm 1.9, \mathrm{p}=0.000)$.

As regards educational level, this table showed that illiterate caregivers have significantly higher mean score of financial burden $(2.5 \pm 1.3)$ than other levels of education of caregivers $(p=0.001)$ while, the secondary school education caregivers have significantly high mean score of basic social functioning burden than others $(\mathrm{p}=0.04)$.

Concerning marital status, this table showed that widow caregivers have significantly higher mean scores of financial burden $(2.5 \pm 1.3, \mathrm{p}=0.003)$, personal distress burden $(8.5 \pm 3.2, \mathrm{p}=0.01)$ and time perspective burden $(8.2 \pm 2.3, \mathrm{p}=0.007)$ than other caregivers.

As regards relative degree of patients, fathers have significantly higher mean scores of financial burden $(2.6 \pm 1.2, \mathrm{p}=0.001)$ than other relatives, while mothers have significantly higher mean scores of personal distress $(10.0 \pm 5.6, \mathrm{p}=0.03)$, and time perspective burden $(9.3 \pm 1.2, \mathrm{p}=0.000)$.

Regarding residence, caregivers live in rural areas have significantly higher mean score of financial burden $(2.3 \pm 1.2, \mathrm{p}=0.003)$ than those live in urban areas. However, those live in urban areas have significantly higher mean scores of disrupted activities $(13.1 \pm 4.1, \mathrm{p}=0.001)$, personal distress $(9.2 \pm 3.3, \mathrm{p}=0.000)$, time perspective $(8.5 \pm 2.6, \mathrm{p}=0.02)$ and basic social functioning $(4.3 \pm 1.7, \mathrm{p}=0.000)$ than those live in rural areas. 
As regards income status and burden, this table showed that, those with insufficient income have significantly the highest mean scores of financial problems $(2.6 \pm 1.2, \mathrm{p}=0.000)$ and personal distress $(7.9 \pm 3.0$, $\mathrm{p}=0.03$ ) and those with sufficient income have significant the highest mean score of basic social functioning $(3.6 \pm 1.8, \mathrm{p}=0.002)$.

\section{Discussion}

Worldwide in the field of mental health care, psychotic patients has shifted from hospital to community. This shifting leads to profound psychosocial, physical and financial burden on family caregivers (Ndetei et.al, 2009). Caregiving has many challenges such as financial loss, time lost from work, limited time for leisure, socializing, and doing other activities (Bernier et.al, 2012).

As related to socio- demographic characteristics of caregivers, most of them in the age group ranged from 45 to less than 60 years. This could be interpreted by; more than half of family caregivers are parents. Also, the older people in upper Egypt are considered the heads of family who have the major responsibility to take care of other family member as they are at home and take the responsibility of caring and play many roles as health provider, care manager, and decision-maker. Similarly, Perkins (2010) reported that, caregivers in the age group of 35-49 years perceived significantly higher impact in the form of disrupted schedule and affected health as compared to caregivers between 21 and 34 years old.

Caregivers in this age group are more likely to have taken on multiple social roles with greater commitments and besides being a caregiver, he/she might be a parent, a spouse and an employee with more responsibilities. Also, Janardhana et al (2015), reported that most number of caregivers were above the age of 51 years, the responsibility lies on the older family member as they are at home and given the responsibility of caring. Moreover, Chang et al (2016) reported that most of the caregivers of mentally ill patients were in the age group of 50-64 years.

In the present study, it was found that two thirds of caregivers were females and this might be related to that females are present at any following up or consultations with mentally ill patients and in the upper Egyptian society, females are more carrying out the responsibilities of the care of ill patients than males. Also, males are preoccupied by other activities like job, working at fields....etc. Moreover, females are more tolerable for patients' needs than males. This result is consistent with Tang et.al, (2013) who reported that more than half and up to three quarters of mentally ill caregivers were females. Moreover, Family Caregiver Alliance (2007) revealed that although men also provide assistance, female caregivers may spend as much as $50 \%$ more time providing care than male caregivers. World Federation of Mental Health (2010) estimated that more than three quarters of caregivers were women and they could be the mother, wife, or daughter. In contrast, Ola (2013) reported that the number of male caregivers of mental illness seems to be on the increase, while in certain cultures men often predominate as caregivers.

Concerning educational level, nearly two thirds of family caregivers were illiterate. The explanation of this finding is; the greatest numbers of caregivers were females and come from rural areas where the chances for education is lower than urban communities so, a high number of caregivers were illiterate. This study agrees with To'meh (2013) who reported that more than half of family caregivers of psychotic patients had an educational level below secondary school education. Also, Souza et al, (2017) reported that more than two thirds of family caregivers had low level of education. In the opposite side, Ndikuno et al, (2016) reported that the Ugandan education programs offer free education for those who may not be able to afford paying for it. This free education leads to increase in number of literate caregivers of mental illness.

The current study revealed that caregivers had the highest mean score of time perspective burden. Time perspective means caregivers are upset about the past of their relatives, stigma in the present and worry about future. It can be explained by family caregivers are sad and upset about the change in patient's condition and think in the past and wish that their patients return to pre- mental illness characteristics or functioning level . Moreover, problems related to stigma do not only affect persons suffering from mental illness but also their families. Stigma adds to the burden of caregiving and affects the lives of family members in multiple ways. For example, other family members would not be able to marry or that friends, relatives or neighbors might avoid treating with them. Also, they may be worried about what the future holds for them when they're no longer around to look out for their patients so, all of these factors increase burden of family caregivers.

The present study showed that caregivers had higher mean score of financial problems when comparing by other subscales of burden except time perspective. It could be explained by that family income is reduced by the fact that patients are unable to work and because the earning potential of other family members is restricted by their caring obligations. At the same time, costs and expenses increase due to needs for medical and other care, frequent readmission to hospital, and comprehensive needs which lead to enormous financial problems. Similarly, the financial burden was found to be more contributing to the overall burden experienced by the caregivers followed by disruption in routine family activities (Kumar\& Saini, 2012). In the same line, Family Caregiver Alliance (2006) demonstrated that, medical advances, shorter hospital stays, limited discharge 
planning, and expansion of home care technology have placed increased costs on families, who are being asked to shoulder greater care burdens for longer periods of time. Moreover, Sintayehu et al (2015) reported that half of caregivers of mentally ill patients had low income. Furthermore, Whiteford et al. (2013) reported that, mental illness had high levels of service use and significant economic costs among family caregivers as they are primary caregivers and provide financial support for their patients. In this respect, McEvoy (2007) reported that the economic impact of mental illness on both caregiver and care recipient is enormous. Direct and indirect costs arise from therapeutic interventions and loss of productivity respectively. Lai (2012) stated that caring for an individual with a mental illness requires notable financial support because of their current nature of the disease. Therefore, medical insurance may not cover certain types of treatment or medications, which could result in financial burdens.

In the current study, the old age caregivers suffered from more burdens, especially the age group from 60 $<75$. This could be related to that the old age caregivers are more vulnerable to many physical diseases that hinder them from providing care to their mentally ill patients and carrying out the responsibility regarding those patients. Also, they become less tolerant to stressors than before. Similarly, Li et al., (2007) in a study conducted in China concluded that the age of the caregivers was positively correlated to their burden. Conversely, Magana et.al, (2007) showed that caregivers with younger age experienced higher level of burden. Younger caregivers, particularly those in midlife, are more likely to have additional major social roles, such as work and other caregiving roles that include raising children and caring for aging parents. Also, Holikatti et al, (2008) reported that subjective burden was positively associated with younger age group and being female.

With regard to education, the result revealed that, illiterate caregivers had the highest mean score of financial problems, personal distress and time perspective burden. This might be explained by that low educated caregivers tend to have low salaries and little resources so their burden increased because they are unable to meet medical needs and costs of their mentally ill patients. This result is supported by Caqueo-Urizar (2006), who reported that, higher educational level of the caregivers had associated with lower burden which may be related to being more informed about the condition and social resources for treatment of the patient and they have knowledge to deal with the stressful event. In addition, Li et al, (2007) reported that the education level has negative correlation with caregivers' burden. It was assumed that higher the level of education, higher the salary would be. High salary will minimize financial strain related to providing care for their ill relative. On the other hand, Pun et.al, (2014) found that level of education is linked with high extent of burden because caregivers with higher level of education were responsible for greater acuity of the complexity of providing care.

The present result reflected that, non-skilled workers had significant financial problems, personal distress and time perspectives. This might be related to non-skilled workers face many obstacles in their life as they have received low attention compared to high skilled workers, strict employment protection, low wages although they work long time and have hard work. Their burden increased when they loss part time of work for caring of their patients. Also, employee had significantly the highest mean score of basic social functioning (missed work). It could be explained by that this group of caregivers had two tasks at the same time ; caring for their patient and doing their job so, they may lost days of work because of caring for patients, making medical follow up for them, or change in their patients' condition. In the same line, Family caregiving alliance (2016) reported that more than two thirds of working caregivers report having to rearrange their work schedule, decrease their hours, or take an unpaid leave in order to meet their caregiving responsibilities. Also, Lasebikan et al (2013) reported that those in employment reported greater burden than the unemployed. In contrast, Feki et al, (2015) reported that a significant burden was found among caregivers without occupation .However, Shamsaei et al (2015) reported that there was no statistical significant correlation between occupation and caregiver burden.

In the present study, widowed caregivers had the highest burden. This might be related to that widowhood causes enormous economic, social and psychological problems. A major problem for widowed person particularly women is economic hardship. When the husband is the only responsible for breadwinner, his widow is now deprived of his income and the nucleus of the family is destroyed. Also, the role of caring for a family member with a mental disorder usually falls on one person and can have negative consequences on their physical, psychological, and social health and increase the burden of caregivers. The problems are worse if they have mentally ill person and they are responsible for caring them. This finding is supported by Neong \& Rashid, (2018) who reported that married caregivers have better quality of life compared to their single, widowed, or divorced counterparts. The reason could be because of higher social security, happiness, peace, and effective care. Married caregivers have been shown to have more support, both physically and emotionally which is an important factor in decreasing burden of caregivers. Also, Jeyagurunathan et.al, (2017) reported that caregivers who were single or widowed had significantly high burden as compared with those who were married. It is possible that these caregivers faced more challenges in the absence of a spouse who could offer support and share some of the distress.

The present study revealed that, mother caregivers had higher burden than other caregivers. This is could be interpreted as mother caregivers spent much time with their patients as they all the time are staying at the home 
and less likely to be employed outside home. They responsible for most aspects of the patient's daily care, such as overseeing pharmacological treatment, ensuring that the environment is calm, helping patients to manage their free time, perform all household activities as (cooking, cleaning,....etc) and dealing with everyday difficulties, all of which constitutes a significant source of burden. This finding is supported by Thara et.al, 2003 which reported that mothers who takes almost all responsibility for caring for the patient with mental illness. They provide the most support of patient, often devoting substantial numbers of hours each day towards taking care of their patients, so they have the highest mean score of burden. In the same line, Caqueo-Uri'zar (2006) reported that mothers show the highest level of burden because they usually are the key carer and assume the totality of the patient care.

The current finding revealed that, urban residents experienced higher burden more than rural. This finding could be related to the environmental factors associated with urban life which make individuals more vulnerable to burden than rural areas. Also, urban caregivers are living away from social support as relatives, friends and neighbors, which is essential for decreasing burden .In the same line, Bedard et.al, (2004) indicated that burden may be higher for caregivers living away from other relatives, friends and neighbors. This study does not agree with Yusuf et.al, (2009) who reported that caregivers from rural areas were more likely to experience a high level of burden, compared with those from urban areas, which could be because of the additional burden associated with travelling long distances to access medical help for their relatives

\section{Conclusion}

Caregivers in the age group of 35-49 years perceived significantly higher impact in the form of disrupted schedule and affected health. Caregiving has many challenges such as financial loss, time lost from work, limited time for leisure, socializing, and doing other activities . Based on the result of the present study it can be concluded that, family caregivers of psychotic patients were highly suffering from burden related to time perspective and financial burden .

\section{Acknowledgement}

I would also like to thank my supervisor Prof. Dr. Alaa El Din Mohmed Darweesh .Thank you for providing me with positive feedback as well as constructive criticism. I would like to acknowledge Professor. Dr. Ikram Ibraheem Mohamed. Thank you for your guided direction and your commitment to making this thesis excellent. I am extremely grateful for the support and guidance. Also, Thank you Ass. Prof.Dr Zamam Ahmed for continually encouraging me when I was overwhelmed.

\section{References}

1. Bedard, M., Koivuranta, A., Stuckey, A., (2004). Health impact on caregivers of providing informal care to a cognitively impaired older adult: rural versus urban settings. Canadian Journal of Rural Medicine, 9, $15-23$.

2. Bernier N and Grignon M (2012): Financing Long-Term Care in Canada. IRPP Study no. 33. Montréal. Institute for Research on Public Policy. Retrieved from: http://irpp.org/research-studies/financing-longterm-care-in-canada/.

3. Boye, B., Bentsen, H., $\quad$ Ulstein, I., $\quad$ Notland, T. H., $\quad$ Lersbryggen, A., $\quad$ Lingjaerde, O., $\quad \&$ Malt, U. F. (2001). Relatives' distress and patients' symptoms and behaviours: a prospective study of patients with schizophrenia and their relatives. Acta Psychiatrica Scandinavica, 104(1), 42-50. doi:10.1034/j.1600-0447.2001.00190.x.

4. Caqueo-Urízar, A., \& Gutiérrez-Maldonado, J. (2006). Burden of Care in Families of Patients with Schizophrenia. Quality of Life Research, 15(4), 719-724. doi:10.1007/s11136-005-4629-2.

5. Chang, S., Zhang, Y., Jeyagurunathan, A., Lau, Y. W., Sagayadevan, V., Chong, S. A., \& Subramaniam, M. (2016). Providing care to relatives with mental illness: reactions and distress among primary informal caregivers. BMC Psychiatry, 16(1). doi:10.1186/s12888-016-0786-9.

6. Family Caregiver Alliance (2006): Caregiver Assessment: Principles, Guidelines and Strategies for Change. Report from a National Consensus Development Conference (Vol. I). San Francisco. Retrieved from : https://bmcpsychiatry.biomedcentral.com/articles/10.1186/s12888-017-1501-1.

7. Family Caregiver Alliance (2007): Caregivers at Risk: A Public Health Concern. Caregiving in California: Issue Paper \#1 . Retrieved from: http://www.caregiver.org/caregiver/jsp/content node.jsp?nodeid=1962.

8. Family Caregiver Alliance (2016). Caregiver Statistics: Work and Caregiving. Retrieved from : https://www.caregiver.org/caregiver-statistics-work-and-caregiving.

9. Feki, R., Feki, I., Smaoui, N., Baati, I., Abida, I., Masmoudi, J., \& Jaoua, A. (2015). The Burden among Caregivers of Patients with Chronic Psychoses. European Psychiatry, 30, 1380. doi:10.1016/s09249338(15)31071-3.

10. Holikatti,P., Kar, S., Shukla, R.,K, Swain, S.P., \& Mishra, A.(2008). Burden on Caregiver of Psychiatric 
In-Patients.

Orissa

Journal of Psychiatry; 16: 37-46.

11. Janardhana, N., Raghunandan, S., Naidu, D., Saraswathi, L., \& Seshan, V. (2015). Care giving of people with severe mental illness: An Indian experience. Indian Journal of Psychological Medicine, 37(2), 184. doi:10.4103/0253-7176.155619.

12. Jeyagurunathan, A. S., $\quad$ Sagayadevan, V., $\quad$ Abdin, E., $\quad$ Zhang, Y., $\quad$ Chang, S., $\quad$ Shafie, S., $\quad \ldots$ Subramaniam, M. (2017). Psychological status and quality of life among primary caregivers of individuals with mental illness: a hospital based study. Health and Quality of Life Outcomes, 15(1). doi:10.1186/s12955-017-0676-y

13. Kumar R, Saini $\mathbf{R}$ (2012). Extent of Burden and Coping Strategies among Caregivers of Mentally-ill Patients. Nursing and Midwifery Research Journal, 8(4), 274 - 284.

14. Lai, D. W. (2012). Effect of Financial Costs on Caregiving Burden of Family Caregivers of Older Adults. SAGE Open, 2(4), 215824401247046. doi:10.1177/2158244012470467.

15. Lasebikan, V., \& Ayinde, O. (2013). Family burden in caregivers of schizophrenia patients: Prevalence and socio-demographic correlates. Indian Journal of Psychological Medicine, 35(1), 60. doi:10.4103/02537176.112205 .

16. Li, J., Lambert, C. E., \& Lambert, V. A. (2007). Predictors of family caregivers' burden and quality of life when providing care for a family member with schizophrenia in the People's Republic of China. Nursing \& Health Sciences, 9(3), 192-198. doi:10.1111/j.1442-2018.2007.00327.x.

17. Logdberg, B., Nilsson, L., Levander, M. T., \& Levander, S. (2004). Schizophrenia, neighborhood, and crime. Acta Psychiatrica Scandinavica, 110(2), 92-97. doi:10.1111/j.16000047.2004.00322.x.

18. Magana, S. M., Ramirez Garcia, J. I., Hernandez, M. G., \& Cortez, R. (2007). Psychological Distress among Latino Family Caregivers of Adults with Schizophrenia: The Roles of Burden and Stigma. Psychiatric Services, 58(3), 378-384. doi:10.1176/appi.ps.58.3.378.

19. McEvoy, J.P. (2007). The costs of schizophrenia. Journal of clinical psychiatry, 68 (14),4-7.

20. Ndetei, D., Pizzo, M., Khasakhala, L., Maru, H., Mutiso, V., Ongecha-Owuor, F., \& Kokonya, D. (2009). Perceived economic and behavioural effects of the mentally ill on their relatives in Kenya: a case study of the Mathari Hospital. African Journal of Psychiatry, 12(4), 293-299. doi:10.4314/ajpsy.v12i4.49050.

21. Ndikuno, C., Namutebi, M., Kuteesa, J., Mukunya, D., \& Olwit, C. (2016). Quality of life of caregivers of patients diagnosed with severe mental illness at the national referral hospitals in Uganda. BMC Psychiatry, 16(1). doi:10.1186/s12888-016-1084-2.

22. Neong , S.C., \&Rashid, A.(2018). Quality of life of caregivers of patients with psychiatric illness in Penang. J Clin Psychiatry Cog Psychol, 2(1), 12-18.

23. Ola, B.A. (2013). The influence of burden of care and perceived stigma on expressed emotions of relatives of stable persons with schizophrenia in Nigerian semi-urban/urban settings (Master thesis). Universidade Nova de Lisboa. Retrieved from: http//run.unl.pt/bitstream/10362/9673/.../Ola Bolanle TM 2013.pdf.

24. Papastavrou, E., $\quad$ Kalokerinou, A., $\quad$ Papacostas, S. S., $\quad$ Tsangari, H., $\quad \& \quad$ Sourtzi, P. (2007). Caring for a relative with dementia: family caregiver burden. Journal of Advanced Nursing, 58(5), 446-457. doi:10.1111/j.1365-2648.2007.04250.x.

25. Perkins, E. A. (2010). The Compound Caregiver: A Case Study of Multiple Caregiving Roles. Clinical Gerontologist, 33(3), 248-254. doi:10.1080/07317111003773619.

26. Pun, K. , Heb, G., Wang, X.(2014). Extent of Burden and Coping among Family Caregivers Living with Schizophrenic Patients in Nepal. International Journal of Sciences, 14(1), 428-443. Retrieved from: http://gssrr.org/index.php?journal=Journal.

27. Reine ,G., Lancon ,C., Simeoni ,M., Duplan, S., \&Auquier, P.(2003). Caregiver burden in relatives of persons with schizophrenia: An overview of measure instruments. Encephale, 29(2), 137-147.

28. Reinhard, S. C., Gubman, G. D., Horwitz, A. V., \& Minsky, S. (1995). Burden assessment scale for families of the seriously mentally ill. Evaluation and Program Planning, 17(3), 261-269. doi:10.1016/01497189(94)90004-3

29. Schulze, B., \& Rössler, W. (2005). Caregiver burden in mental illness: review of measurement, findings and interventions in 2004-2005. Current Opinion in Psychiatry, 18(6), 684-691. doi:10.1097/01.yco.0000179504.87613.00

30. Shamsaei, F., Cheraghi, F., \& Esmaeilli, R. (2015). The Family Challenge of Caring for the Chronically Mentally Ill: A Phenomenological Study. Iranian Journal of Psychiatry and Behavioral Sciences, 9(3). doi:10.17795/ijpbs-1898

31. Sintayehu, M., Mulat, H., Yohannis, Z., Adera, T., \& Fekade, M. (2015). Prevalence of mental distress and associated factors among caregivers of patients with severe mental illness in the outpatient unit of 
Amanuel Hospital, Addis Ababa, Ethiopia, 2013: Cross-sectional study. Journal of Molecular Psychiatry, 3(1). doi:10.1186/s40303-015-0014-4.

32. Souza, A. L., Guimarães, R. A., De Araújo Vilela, D., De Assis, R. M., De Almeida Cavalcante Oliveira, L. M., Souza, M. R., ... Barbosa, M. A. (2017). Factors associated with the burden of family caregivers of patients with mental disorders: a cross-sectional study. BMC Psychiatry, 17(1). doi:10.1186/s12888-017-1501-1.

33. Swaroop, N., Ravi ,S., Goud, R., Archana, M., Pius , T., Pal, A., John, V., Agrawal ,T., \& Jayaram,G.(2013):Burden among Caregivers of Mentally- Ill Patients: A Rural Community - Based Study. Int J Res Dev Health, 1(2).

34. Tang, B., Harary, E., Kurzman, R., Mould-Quevedo, J. F., Pan, S., Yang, J., \& Qiao, J. (2013): Clinical Characterization and the Caregiver Burden of Dementia in China. Value in Health Regional Issues, 2(1), 118-126. doi:10.1016/j.vhri.2013.02.010.

35. Thara, R., Kamath, S., \&Kumar, S. (2003). Women with schizophrenia and broken marriages-doubly disadvantaged? Part II: Family perspective. Int J Soc Psychiatr, 49(3), 233240.

36. To'meh, H. (2013). Family burden among caregivers of mentally ill patients in Nablus District (Master's Thesis) . An-Najah National University, Palestine. Retrieved from : https://staffold.najah.edu/sites/default/files/Family_Burden_among_Caregivers_of_Mentally_Ill_Patients_in_Nablus_ District.pdf

37. Whiteford, H. A., Degenhardt, L., Rehm, J., Baxter, A. J., Ferrari, A. J., Erskine, H. E., ... Vos, T. (2013). Global burden of disease attributable to mental and substance use disorders: findings from the Global Burden of Disease Study 2010. The Lancet, 382(9904), 1575-1586. doi:10.1016/s01406736(13)61611-6.

38. World Federation of Mental Health (WFMH) (2010). Caring for the caregiver: Why your mental health matters when you are caring for others. Woodbridge VA: WFMH. Retrieved from. http://www.ijpcm.org/index.php/IJPCM/article/download/26/40

39. Yusuf, A. J., Nuhu, F. T., \& Akinbiyi, A. (2009). Caregiver burden among relatives of patients with schizophrenia in Katsina, Nigeria. South African Journal of Psychiatry, 15(2), 5. doi:10.4102/sajpsychiatry.v15i2.187. 